$\begin{array}{llcccccrr}\text { Volume } & 12, \quad \text { Nomor } & 1, \quad \text { Mei } & \text { 2020, } & \text { pp } & 84-98 & \text { Copyright } & \text { C } & 2017 \\ \text { Jurnal } & \text { Akuntansi, } & \text { Program } & \text { Studi } & \text { Akuntansi, } & \text { Fakultas } & \text { Ekonomi, } \\ \text { Universitas } & \text { Kristen } & \text { Maranatha. } & \text { ISSN } & 2085-8698 & \text { e-ISSN } & 2598-4977 .\end{array}$

http://journal.maranatha.edu

\title{
Pengaruh Current Ratio, Debt to Equity Ratio, Return on Assets, Growth dan Firm Size terhadap Kebijakan Dividen: Studi pada Perusahaan yang Tercatat Aktif di BEI yang Membagikan Dividen Periode 2012-2015
}

\author{
Mikael Abraham Deswanto Prabowo \\ Fakultas Ekonomi Program Magister Manajemen-Univ.Katolik Parahyangan \\ (Jl. Merdeka No. 30, Bandung) \\ mikael.babam@gmail.com \\ Clara Alverina \\ Fakultas Ekonomi Program Studi Manajemen-Univ.Katolik Parahyangan \\ (Jl. Ciumbuleuit No. 94, Bandung) \\ claralverina01@gmail.com
}

\begin{abstract}
This paper aims to determine the effect of liquidity, solvency, profitability, growth and firm size on the dividend payout ratio. Population and sample are companies that routinely distribute dividends that are listed on the Indonesia Stock Exchange website during the period of 2012 to 2015. To obtain valid research results, the sampling technique used in this study was using purposive sampling technique. The method of analysis is done by using classical testing on five independent variables then $F$ test and t test.
\end{abstract}

Keywords: Current Ratio (CR), Debt to Equity Ratio (DER), Return On Assets (ROA), Growth, Firm Size, and Dividen Payout Ratio (DPR)

\begin{abstract}
Abstrak
Makalah ini bertujuan untuk mengetahui pengaruh likuiditas, solvabilitas, profitabilitas, pertumbuhan dan ukuran perusahaan terhadap rasio pembayaran dividen. Populasi dan sampel penelitian adalah perusahaan yang secara rutin membagikan dividen yang terdaftar pada situs web Bursa Efek Indonesia selama periode 2012 hingga 2015. Untuk mendapatkan hasil penelitian yang valid, teknik pengambilan sampel yang digunakan dalam penelitian ini menggunakan teknik purposive sampling. Metode analisis dilakukan dengan menggunakan uji klasik pada lima variabel bebas kemudian uji $\mathrm{F}$ dan uji t.
\end{abstract}

Kata Kunci: Current Ratio (CR), Debt to Equity Ratio (DER), Return On Assets (ROA), Growth, Firm Size, and Dividen Payout Ratio (DPR) 


\section{Pendahuluan}

Perusahaan bertujuan untuk memaksimalkan kesejahteraan pemegang saham (shareholder) melalui keputusan atau kebijakan investasi, keputusan pendanaan dan keputusan dividen, demikian jika dilihat berdasarkan sudut pandang manajemen keuangan. Tujuan ini sering diterjemahkan sebagai suatu usaha untuk memaksimalkan nilai perusahaan. Dalam mencapai tujuan tersebut, banyak shareholder yang menyerahkan pengelolaan perusahaan kepada para profesional yang bertanggungjawab mengelola perusahaan, yang disebut manajer. Para manajer yang diangkat oleh shareholder diharapkan akan bertindak atas nama shareholder tersebut, yakni memaksimalkan nilai perusahaan sehingga kemakmuran shareholder akan tercapai.

Kasmir dan Jakfar (2012), menyatakan para investor mempunyai tujuan untuk meningkatkan kesejahteraannya dengan mengharapkan return dalam bentuk capital gain maupun dividen. Selain itu, perusahaan mengharapkan pertumbuhan, sekaligus mempertahankan kelangsungan hidupnya dan memberikan kesejahteraan bagi shareholder. Kebijakan pembayaran dividen mempunyai dampak yang sangat penting bagi investor maupun bagi perusahaan yang membayarkan dividen. Dengan demikian, kebijakan pembagian dividen menjadi masalah yang serius, disisi lain agar tidak menghambat pertumbuhan serta kelangsungan hidup perusahaan.

Laba yang akan dibagikan sebagai dividen disebut sebagai dividend payout ratio (DPR). Semakin tinggi dividend payout ratio maka semakin kecil porsi dana yang tersedia untuk ditanamkan kembali dalam perusahaan. Pertimbangan mengenai dividend payout ratio ini sangat berkaitan dengan kinerja keuangan perusahaan. Bila kinerja keuangan bagus maka perusahaan tersebut akan mampu menetapkan besarnya dividend payout ratio sesuai dengan harapan shareholder dan tentu saja tanpa mengabaikan kepentingan perusahaan untuk tetap tumbuh dan berkembang menurut Sugiyono (2010).

Penelitian yang dilakukan oleh Santosa (2009) mengatakan bahwa current ratio tidak memiliki pengaruh yang signifikan terhadap dividend payout ratio. Hal ini berbeda dengan hasil penelitian yang dilakukan oleh Orniati (2009) yang menyatakan current ratio berpengaruh signifikan terhadap dividend payout ratio. Deitiana (2009) dan Sutari (2011) dalam penelitiannya menyatakan bahwa debt to equity ratio tidak memiliki pengaruh yang signifikan terhadap dividend payout ratio. Hal ini bertentangan dengan penelitian yang dilakukan oleh Cendekia dan Irine (2010) yang menyatakan bahwa debt to equity ratio berpengaruh signifikan terhadap dividend payout ratio.

Penelitian yang dilakukan oleh Prasetyo (2013) menunjukkan bahwa dividend payout ratio dipengaruhi secara signifikan oleh return on asset. Hal ini berbeda dengan hasil penelitian yang dilakukan oleh Sutoyo, et al. (2011) yang menyatakan bahwa return on asset tidak berpengaruh signifikan terhadap dividend payout ratio.

Penelitian growth perusahaan yang dilakukan oleh Nadjibah (2008) menyatakan bahwa growth berpengaruh negatif dan signifikan terhadap dividend payout ratio. Berbeda dengan penelitian Swastyastu, Yuniarta, dan Atmadja (2014) menjelaskan growth tidak berpengaruh terhadap dividend payout ratio.

Amalia (2008) dalam penelitiannya mengenai faktor-faktor yang mempengaruhi dividend payout ratio perusahaan yang listed di Bursa Efek Indonesia (BEI) mengatakan bahwa untuk perusahaan yang sebagian sahamnya tidak dimiliki oleh manajemen perusahaan, firm size memiliki pengaruh signifikan terhadap dividend payout ratio. Hal ini didukung oleh penelitian yang dilakukan oleh Sutari (2011) yang mengatakan bahwa firm size memiliki pengaruh signifikan terhadap 
dividend payout ratio. Namun berdasarkan penelitian Sutoyo, et al. (2011), Prasetyo (2013) serta Cendekia dan Irine (2010) diperoleh kesimpulan bahwa firm size tidak memiliki pengaruh signifikan terhadap dividend payout ratio.

Berdasarkan uraian tersebut, penelitian bertujuan mengukur pengaruh atas rasio likuiditas yang diproksikan oleh $\mathrm{CR}$, rasio solvabilitas yang diproksikan oleh DER, rasio profitabilitas yang diproksikan oleh ROA, growth dan firm size terhadap dividend payout ratio (DPR) pada perusahaan yang terdaftar di Bursa Efek Indonesia pada tahun 2012-2015.

\section{Kerangka Teoritis dan Hipotesis}

\section{Current Ratio (CR)}

Current ratio ini mengukur seberapa jauh aktiva lancar perusahaan bisa dipakai untuk memenuhi kewajiban lancarnya. Rasio ini digunakan sebagai tolak ukur atas keuangan perusahaan dalam memenuhi utang atau kewajiban jangka pendek tersebut. Current ratio menunjukkan besarnya utang kewajiban lancar yang ditutup dengan aktiva yang diharapkan akan dikonversi menjadi kas dalam jangka pendek (aktiva lancar). Current ratio merupakan salah satu ukuran dari rasio likuiditas yang dihitung dengan membagi aktiva lancar (current assets) dengan utang atau kewajiban lancar (current liability). Semakin besar current ratio menunjukkan semakin tinggi kemampuan perusahaan dalam memenuhi kewajiban jangka pendeknya (Kasmir, 2012: 79).

$$
\text { Current Ratio }=\frac{\text { Current Assets }}{\text { Curent Liabilities }}
$$

Penelitian terhadap faktor-faktor yang mempengaruhi kebijakan dividen payout ratio sudah banyak dilakukan, akan tetapi hasil penelitian tidak konsisten satu sama lain meskipun penelitian tersebut sejenis. Penelitian yang dilakukan oleh Santosa
(2009) mengatakan bahwa current ratio tidak memiliki pengaruh yang signifikan terhadap dividend payout ratio. Hal ini berbeda dengan hasil penelitian yang dilakukan oleh Orniati (2009) yang menyatakan current ratio berpengaruh signifikan terhadap dividend payout ratio.

\section{Debt to Equity Ratio (DER)}

Rasio total utang terhadap modal sendiri atau debt to equity ratio merupakan salah satu dari rasio manajemen utang atau sering disebut dengan rasio leverage menurut Kasmir (2012: 84). Rasio leverage ini digunakan untuk menjelaskan penggunaan utang untuk membiayai sebagian daripada aktiva perusahaan. Penggunaan utang yang efisien adalah penggunaan dengan biaya rendah untuk memaksimalkan laba.

$$
\text { Debt to Equity Ratio }=\frac{\text { Total Liabilities }}{\text { Total Equity }}
$$

Menurut Kasmir (2012:157), debt to equity ratio adalah rasio yang digunakan untuk menilai utang dengan ekuitas. Rasio ini dicari dengan membandingkan antara seluruh utang, termasuk utang lancar dengan seluruh ekuitas. Rasio ini berguna untuk mengetahui jumlah dana yang disediakan peminjam (kreditor) dengan pemilik perusahaan. Dengan kata lain, rasio ini berfungsi untuk mengetahui setiap rupiah modal sendiri yang dijadikan untuk jaminan utang.

Oleh karena itu semakin rendah $D E R$ akan semakin tinggi kemampuan perusahaan untuk membayar seluruh kewajibannya. Peningkatan hutang pada gilirannya akan mempengaruhi besar kecilnya laba bersih yang tersedia bagi para pemegang saham termasuk dividend yang akan diterima, karena kewajiban lebih diprioritaskan daripada pembagian dividend.

Deitiana (2009) dan Sutari (2011) dalam penelitiannya menyatakan bahwa debt to equity ratio tidak memiliki pengaruh yang signifikan terhadap dividend payout ratio. Hal ini bertentangan dengan 
penelitian yang dilakukan oleh Cendekia dan Irine (2010) yang menyatakan bahwa debt to equity ratio berpengaruh signifikan terhadap dividend payout ratio.

\section{Return On Assets}

Return on asset atau tingkat pengembalian atas total aktiva merupakan rasio laba bersih terhadap total aktiva. Rasio ini mengukur pengembalian atas total aktiva setelah bunga dan pajak menurut Kasmir (2012: 90). Pengembalian atas aktiva memberikan suatu ukuran efisiensi perusahaan secara keseluruhan. Semakin besar return on asset menunjukkan kinerja perusahaan yang semakin baik, karena tingkat pengembalian investasi (return) semakin besar.

$$
\text { Return On Assets }=\frac{\text { Earning After Tax }}{\text { Total Assets }}
$$

Di samping itu hasil pengembalian investasi menunjukkan produktivitas dari seluruh dana perusahaan, baik modal pinjaman maupun modal sendiri. Semakin rendah (kecil) rasio ini semakin kurang baik, demikian pula sebaliknya. Artinya rasio ini digunakan untuk mengukur efektivitas dari keseluruhan operasi perusahaan.

Return on asset (ROA) adalah rasio yang menunjukan hasil (return) atas jumlah aktiva yang digunakan dalam perusahaan. Selain itu, $R O A$ memberikan ukuran yang lebih baik atas profitabilitas perusahaan karena menunjukan efektivitas manajemen dalam menggunakan aktiva untuk memperoleh pendapatan menurut Kasmir (2012: 201).

Penelitian yang dilakukan oleh Prasetyo (2013) menunjukan bahwa dividend payout ratio dipengaruhi secara signifikan oleh return on asset. Hal ini berbeda dengan hasil penelitian yang dilakukan oleh Sutoyo, et al. (2011) yang menyatakan bahwa return on asset tidak berpengaruh signifikan terhadap dividend payout ratio.

\section{Growth}

Aset adalah aktiva yang digunakan untuk aktivitas operasional perusahaan. Semakin besar aset maka diharapkan semakin besar pula hasil operasional yang dihasilkan oleh suatu perusahaan. Peningkatan aset yang diikuti peningkatan hasil operasi akan semakin menambah kepercayaan pihak luar terhadap perusahaan. Dengan meningkatnya kepercayaan pihak luar (kreditur) terhadap perusahaan, maka proporsi hutang semakin lebih besar dari modal sendiri.

Makin cepat tingkat pertumbuhan suatu perusahaan, makin besar kebutuhan dana untuk waktu mendatang untuk membiayai pertumbuhanya. Perusahaan tersebut biasanya akan lebih senang untuk menahan pendapatannya daripada dibayarkan sebagai dividen dengan mengingat batasan-batasan biayanya.

Growth $=$

Total Asssets Tahun $t-$ Total Assets Tahun $t-1$

$$
\text { Total Assets Tahun } t-1
$$

Growth menunjukkan pertumbuhan aset dimana aset merupakan aktiva yang digunakan untuk aktifitas operasional perusahaan. Growth menunjukkan pertumbuhan aset, perusahaan dengan kesempatan pertumbuhan yang tinggi memiliki free cash flow yang rendah karena sebagian dana yang ada digunakan untuk investasi pada proyek yang memiliki nilai $N V P$ positif. Dapat disimpulkan bahwa terdapat hubungan yang negatif antara pertumbuhan dan pembayaran dividen menurut Kasmir (2012).

Penelitian growth perusahaan yang dilakukan oleh Nadjibah (2008) menyatakan bahwa growth berpengaruh negatif dan signifikan terhadap dividend payout ratio. Berbeda dengan penelitian Swastyastu, Yuniarta, dan Atmadja (2014) yang menjelaskan bahwa growth tidak berpengaruh terhadap dividend payout ratio. 


\section{Firm Size}

Dalam pembagian dividen biasanya perusahaan baru membagikan labanya dalam bentuk dividen setelah mencapai titik kedewasaan dalam daur hidupnya. Firm size adalah tingkat untuk menunjukkan perkembangan perusahaan dalam bisnis yang dinyatakan oleh Rizqia (2013). Firm size dianggap mampu mempengaruhi kebijakan dividen, semakin besar ukuran perusahaan maka akan semakin mudah pula perusahaan-perusahaan memperoleh sumber pendanaan baik yang internal maupun eksternal.

\section{Firm Size $=$ Ln(Total Assets $)$}

Firm size adalah ukuran perusahaan. Faktor ini menjelaskan bahwa suatu perusahaan besar memiliki akses yang lebih mudah ke pasar modal, sedangkan perusahaan kecil tidak mudah. Kemudahan aksesibilitas ke pasar modal merupakan fleksibilitas dan kemampuan perusahaan untuk menciptakan hutang atau memunculkan dana yang lebih besar dengan catatan perusahaan tersebut memiliki ratio pembayaran dividen yang lebih tinggi daripada perusahaan kecil.

Amalia (2008) dalam penelitiannya mengenai faktor-faktor yang mempengaruhi dividend payout ratio perusahaan yang listed di Bursa Efek Indonesia mengatakan bahwa untuk perusahaan yang sebagian sahamnya tidak dimiliki oleh manajemen perusahaan, firm size memiliki pengaruh signifikan terhadap dividend payout ratio. Hal ini didukung oleh penelitian yang dilakukan oleh Sutari (2011) yang mengatakan bahwa firm size memiliki pengaruh signifikan terhadap dividend payout ratio. Namun berdasarkan penelitian Sutoyo, et al. (2011), Prasetyo (2013) serta Cendekia dan Irine (2010) diperoleh kesimpulan bahwa firm size tidak memiliki pengaruh signifikan terhadap dividend payout ratio.

\section{Model Penelitian Dan Pengembangan Hipotesis}

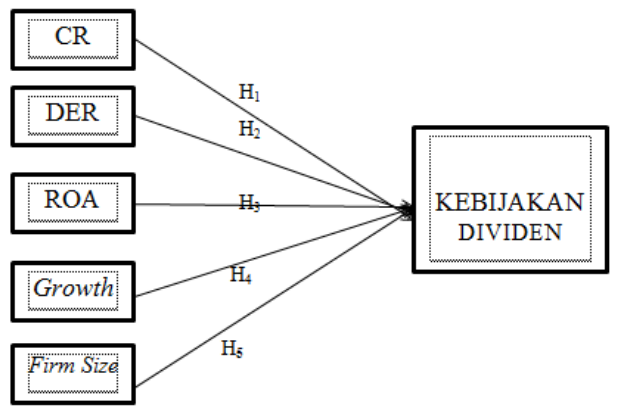

Gambar 1

Model Penelitian

H1: Terdapat pengaruh positif signifikan secara parsial antara CR terhadap kebijakan dividen.

$\mathrm{H} 2$ : Terdapat pengaruh positif signifikan secara parsial antara DER terhadap kebijakan dividen.

H3: Terdapat pengaruh positif signifikan secara parsial antara ROA terhadap kebijakan dividen.

H4: Terdapat pengaruh positif signifikan secara parsial antara growth terhadap kebijakan dividen.

H5: Terdapat pengaruh positif signifikan secara parsial antara firm size terhadap kebijakan dividen.

\section{Metode Penelitian}

Jenis penelitian yang digunakan eksplanatori dengan pendekatan kuantitatif. Adapun penelitian eksplanatori menurut Sugiyono (2010) adalah penelitian yang menjelaskan hubungan kausal antara variabel-variabel yang mempengaruhi hipotesis. Selain itu, penelitian ini menggunakan hypothesis-testing yaitu untuk menguji pengaruh variabel independen terhadap variabel dependen.

\section{Populasi dan Sampel}

Pada penelitian ini, yang menjadi populasi adalah seluruh perusahaan di Bursa Efek Indonesia (BEI) yang melakukan 
pembayaran dividen. Teknik sampel yang digunakan dalam penelitian ini adalah purposive sampling yaitu pemilihan sampel dengan kriteria tertentu. Dalam penelitian ini kriterianya adalah perusahaan yang membayarkan dividen tunai secara berturutturut selama periode pembayaran yaitu pada tahun 2012-2015.

Data dalam penelitian ini bersumber dari annual report perusahaan yang dipublikasikan di website Bursa Efek Indonesia (www.idx.co.id). Jenis data yang digunakan dalam penelitian ini adalah data sekunder berupa dividen per share, earning per share, current assets, current liabilities, total liabilities, total equity dan earning after tax yang diperoleh dari laporan tahunan perusahaan tahun 2012-2015.

Adapun kriteria atau pertimbangan pengambilan sampel yang digunakan penulis adalah:

1. Perusahaan telah terdaftar di Bursa Efek Indonesia (BEI)

2. Tidak delisting selama periode pengamatan tahun

3. Memberikan laporan keuangan secara periodik kepada Bursa Efek Indonesia dan dipublikasikan di website resmi BEI.

4. Perusahaan menyediakan data yang lengkap, sesuai dengan yang dibutuhkan dalam penelitian ini.

\section{Teknik Pengumpulan Data}

Dalam penelitian ini, penulis mengumpulkan data yang dibutuhkan dengan menggunakan teknik sebagai berikut:

1. Penelitian Lapangan

Dalam penelitian ini, penulis melakukan observasi pada obyek penelitian dengan tujuan untuk memperoleh data sekunder, yaitu dengan melakukan penelitian pada situs resmi Bursa Efek Indonesia yang beralamat di www.idx.co.id.

2. Studi Pustaka

Dalam penelitian ini, penulis melakukan studi kepustakaan dengan cara mempelajari, mengkaji dan menelaah literatur-literatur berupa buku, jurnal, berita, dan artikel blog di internet yang ada kaitanya dengan masalah yang diteliti.

\section{Hasil Penelitian dan Pembahasan}

\section{Uji Hipotesis}

Dalam penelitian ini, peneliti menggunakan uji signifikansi simultan (Uji statistik F) dan uji signifikansi parameter individual (Uji statistic t):

1. Uji Statistik F: pengujian dilakukan dengan significance level $0,05(\alpha=5 \%)$ dengan ketentuan yaitu jika nilai sign. $\leq 0,05$ maka hipotesis diterima (koefisien regresi signifikan) artinya secara simultan kelima variabel independen mempunyai pengaruh signifikan terhadap variabel dependen. Sedangkan jika nilai sign. > 0,05 maka hipotesis ditolak (koefisien regresi tidak signifikan) artinya secara simultan variabel independen tidak mempunyai pengaruh yang signifikan terhadap variabel dependen.

2. Uji statistik t: pengujian dilakukan dengan significance level $0,05(\alpha=5 \%)$ dengan ketentuan yaitu jika nilai sign. $\leq 0,05$ maka hipotesis diterima (koefisien regresi signifikan) artinya secara parsial variabel independen mempunyai pengaruh yang signifikan terhadap variabel dependen. Sedangkan jika nilai sign. > 0,05 maka hipotesis ditolak (koefisien regresi tidak signifikan) artinya secara parsial variabel independen tidak mempunyai pengaruh yang signifikan terhadap variabel dependen.

Berdasarkan pengolahan data, maka peneliti menemukan hasil sebagai berikut: 


\section{Metode Analisis Data (Descriptive Statistic)}

Variabel yang digunakan dalam penelitian ini adalah $C R, D E R, R O A$, growth dan firm size sebagai variabel independen dan dividend payout ratio sebagai variabel dependen.

Gambaran mengenai rata-rata, simpangan baku, nilai minimum dan nilai maksimum dari keseluruhan perusahaan berdasarkan masing-masing variabel dapat dilihat pada tabel statistik deskriptif dibawah ini:

\section{Tabel 1}

\begin{tabular}{|l|r|r|r|r|r|}
\hline & N & Minimum & Maximum & Mean & Std. Deviation \\
\hline DPR & 120 & 3.50 & 75411.53 & 954.59 & 6905.85 \\
\hline CR & 120 & 60.17 & 656.74 & 219.31 & 119.56 \\
\hline DER & 120 & .16 & 6.45 & 1.03 & 1.00 \\
ROA & 120 & 1.15 & 71.51 & 13.61 & 11.28 \\
\hline GROWTH & 120 & -58.17 & 259.07 & 16.19 & 31.91 \\
SIZE & 120 & 25.46 & 33.13 & 29.72 & 1.76 \\
Valid N. (listwise) & 120 & & & & \\
\hline
\end{tabular}

Tabel statistik deskriptif menyajikan ringkasan statistik dari variabel-variabel utama penelitian ini. Jumlah data penelitian adalah 120 observasi dengan sampel total penelitian ini terdiri dari 300 perusahaan yang sesuai dengan ciri dan karakter yang diinginkan penelitian yang mana membayar dividen kepada investornya selama proses periode penelitian.

\section{Pengujian Asumsi Klasik (dengan Lima Variabel Independen)}

\section{a. Uji Normalitas}

Uji normalitas bertujuan untuk menguji apakah dalam model regresi, data residual memiliki distribusi normal. Untuk menguji apakah distribusi data normal atau tidak, ada dua cara untuk mendeteksinya, yaitu dengan analisis grafik dan uji statistik.
Tabel 2

One-Sample Kolmogorov-Smirnov Test

\begin{tabular}{|c|c|c|}
\hline & & Unstandardized Residual \\
\hline $\mathrm{N}$ & & 120 \\
\hline \multirow[t]{2}{*}{ Normal Parameters ${ }^{2, b}$} & Mean & .0000000 \\
\hline & Std. Deviation & 21.14214375 \\
\hline \multirow[t]{3}{*}{ MostExtreme Differences } & Absolute & .285 \\
\hline & Positive & .285 \\
\hline & Negative & -.247 \\
\hline \multicolumn{2}{|l|}{ Kolmogorov-Smimov Z } & .903 \\
\hline \multicolumn{2}{|l|}{ Asymp. Sig. (2-tailed) } & .389 \\
\hline
\end{tabular}

Uji Kolmogorov - Smirnov menunjukkan nilai sebesar 0.389 yang berada di atas 0.05 maka sesuai dengan dasar pengambilan keputusan dalam uji normalitas kolmogorv - smirnov diatas, dapat disimpulkan bahwa data berdistribusi normal. Dengan demikian, asumsi atau persyaratan normalitas dalam model regresi sudah terpenuhi.

\section{b. Uji Multikolinearitas}

Uji multikolinearitas bertujuan untuk menguji apakah dalam model regresi ditemukan adanya korelasi antar variabel independen. Jika variabel independen saling berkorelasi, maka variabel-variabel ini tidak ortogonal. Untuk mengetahui ada tidaknya multikolinearitas di dalam model regresi dapat dilihat dari nilai tolerance dan variance inflation factor (VIF).

Tabel 3

Coefficients $^{\mathrm{a}}$

\begin{tabular}{|c|c|c|c|}
\hline \multirow{2}{*}{\multicolumn{2}{|c|}{ Model }} & \multicolumn{2}{|c|}{ Collinearity Statistics } \\
\hline & & Tolerance & VIF \\
\hline \multirow{6}{*}{1} & (Constant) & & \\
\hline & $\mathrm{CR}$ & 0.98 & 1.021 \\
\hline & DER & 0.981 & 1.019 \\
\hline & ROA & 0.985 & 1.015 \\
\hline & GROWTH & 0.914 & 1.094 \\
\hline & SIZE & 0.91 & 1.099 \\
\hline
\end{tabular}


Variabel independen dinyatakan bebas dari multikolinearitas jika mempunyai nilai tolerance di atas 0.1 dan nilai VIF di bawah 10. Dari Tabel 3 dapat diketahui bahwa semua variabel independen memiliki nilai tolerance di atas 0.1 dan nilai VIF jauh di bawah angka 10. Hal ini menunjukkan dalam model ini tidak terjadi multikolinearitas.

\section{c. Uji Heteroskedastisitas}

Uji heteroskedastisitas bertujuan untuk menguji apakah terjadi ketidaksamaan varian dari residual satu pengamatan ke pengamatan yang lain.

Jika varian dari residual satu pengamatan terhadap pengamatan yang lain tetap, maka disebut homoskedastisitas dan jika berbeda akan disebut heteroskedastisitas. Model regresi yang baik adalah model yang tidak terjadi heteroskedastisitas.

Deteksi ada tidaknya heteroskedastisitas dapat dilakukan dengan melihat ada tidaknya pola tertentu pada gambar scatterplot antara SRESID dan ZPRED.

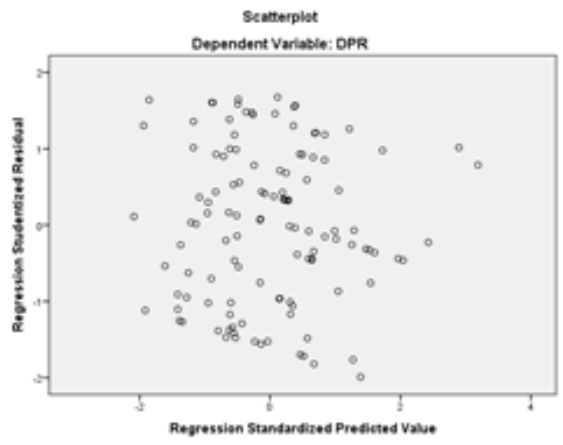

Gambar 2

Pada grafik SRESID dan ZPRED terlihat titik-titik menyebar secara acak dan juga terlihat titik-titik tersebut membentuk suatu pola tertentu. Dengan demikian dapat disimpulkan bahwa penelitian ini terbebas dari masalah heteroskedastisitas.

\section{Uji Hipotesis (dengan Lima Variabel Independen)}

\section{a. Uji Statistik F}

Uji F digunakan untuk mengetahui apakah variabel dependen (CR, DER, ROA, growth dan firm size) secara bersama-sama memiliki pengaruh terhadap variabel independen (DPR).

\begin{tabular}{|c|c|c|c|c|c|}
\hline \multicolumn{6}{|c|}{ ANOVA $^{\mathrm{a}}$} \\
\hline Model & Sum of Squares & $\mathrm{df}$ & Mean Square & $\mathrm{F}$ & Sig. \\
\hline 1 Regression & 68.885 & 5 & 13.777 & 5.426 & $.002^{b}$ \\
\hline Residual & 1079.252 & 114 & 19.467 & & \\
\hline Total & 1148.138 & 119 & & & \\
\hline
\end{tabular}

Pada tabel 4, diperoleh nilai signifikansi sebesar 0.002 yang lebih kecil dari 0.05. Disimpulkan bahwa $C R, D E R$, $R O A$, growth dan firm size secara simultan atau bersama-sama memiliki pengaruh yang signifikan terhadap DPR.

\section{b. Uji Statistik t}

Uji statistik $\mathrm{t}$ ini dilakukan untuk mengetahui pengaruh dari $C R, D E R, R O A$, Growth dan Firm Size terhadap DPR.

Tabel 5

Coefficients $^{\mathrm{a}}$

\begin{tabular}{|l|r|r|r|r|r|}
\hline \multirow{2}{*}{ Model } & \multicolumn{1}{|c|}{ Coefficients $^{\mathrm{a}}$} \\
\cline { 2 - 5 } & \multicolumn{1}{|c|}{$\mathrm{B}$} & Std. Error & \multicolumn{1}{c|}{ Beta } & \multicolumn{1}{c|}{ Sig. } \\
\hline 1 (Constant) & 39.075 & 7.053 & & 5.540 & .000 \\
\hline CR & 12.071 & .010 & 113 & 1.227 & .048 \\
DER & .259 & 1.144 & .021 & .227 & .222 \\
ROA & 1.142 & 1.010 & .161 & 1.764 & .011 \\
GROWTH & $-24,978$ & .017 & .005 & -.050 & .026 \\
SIZE & .235 & .146 & .153 & 1.610 & .027 \\
\hline
\end{tabular}

Berdasarkan tabel 5, variabel current ratio, ROA, growth dan firm size dengan nilai signifikan masing-masing berada dibawah 0,05 yang berarti tolak $\mathrm{H}_{0}$ yang berarti bahwa terdapat pegaruh signifikan secara parsial antara variabel terkait terhadap kebijakan dividen.

Sedangkan variabel DER dengan nilai signifikansi sebesar 0,222 yang mana lebih 
besar dari 0,05 artinya data tidak mampu menolak $\mathrm{H}_{0}$, tidak terdapat pengaruh signifikan secara parsial antara DER dengan kebijakan dividen. Oleh karena itu, variabel DER tidak diikutsertakan dalam model regresi dan dilakukan pengujian ulang.

\section{Pengujian Asumsi Klasik (dengan Empat Variabel Independen)}

\section{a. Uji Normalitas}

Tabel 6

One-Sample Kolmogorov-Smirnov Test

\begin{tabular}{|c|c|c|}
\hline & & $\begin{array}{c}\text { Unstandardized } \\
\text { Residual } \\
\end{array}$ \\
\hline $\mathrm{N}$ & & 120 \\
\hline \multirow[t]{2}{*}{ Normal Parameters ${ }^{a, b}$} & Mean & .0000000 \\
\hline & Std. Deviation & 2.84273472 \\
\hline \multirow[t]{3}{*}{ Most Extreme Differences } & Absolute & .326 \\
\hline & Positive & .274 \\
\hline & Negative & -.326 \\
\hline \multicolumn{2}{|l|}{ Test Statistic } & .326 \\
\hline \multicolumn{2}{|l|}{ Asymp. Sig. (2-tailed) } & $.237^{c}$ \\
\hline
\end{tabular}

Uji normalitas hanya menggunakan empat variabel independen yaitu $C R, R O A$, growth dan firm size. Uji Kolmogorov - Smirnov menunjukkan nilai sebesar 0.237 yang berada di atas 0.05 . Dari hasil pengujian tersebut menunjukkan bahwa data telah terdistribusi normal.

\section{b. Uji Multikolinearitas}

Untuk mengetahui ada tidaknya multikolinearitas di dalam model regresi dapat dilihat dari nilai tolerance dan variance inflation factor (VIF).
Tabel 7

Coefficients $^{a}$

\begin{tabular}{|c|c|c|c|}
\hline \multirow{2}{*}{ Model } & & \multicolumn{2}{|c|}{ Collinearity Statistics } \\
\hline & & Tolerance & VIF \\
\hline \multirow{5}{*}{1} & (Constant) & & \\
\hline & $\mathrm{CR}$ & 0.91 & 1.024 \\
\hline & ROA & 0.95 & 1.011 \\
\hline & GROWTH & 0.94 & 1.046 \\
\hline & SIZE & 0.19 & 1.079 \\
\hline
\end{tabular}

Variabel independen dinyatakan bebas dari multikolinearitas jika mempunyai nilai tolerance di atas 0.1 dan nilai VIF di bawah 10. Dari Tabel 7 dapat diketahui bahwa semua variabel independen memiliki nilai tolerance di atas 0.1 dan nilai VIF jauh di bawah angka 10. Hal ini menunjukkan dalam model ini tidak terjadi multikolinearitas.

\section{c. Uji Heteroskedastisitas}

Deteksi ada tidaknya heteroskedastisitas dapat dilakukan dengan melihat ada tidaknya pola tertentu pada gambar scatterplot antara SRESID dan ZPRED.

Pada grafik SRESID dan ZPRED terlihat titik-titik menyebar secara acak dan juga terlihat titik-titik tersebut membentuk suatu pola tertentu. Dengan demikian dapat disimpulkan bahwa penelitian ini terbebas dari masalah heteroskedastisitas.

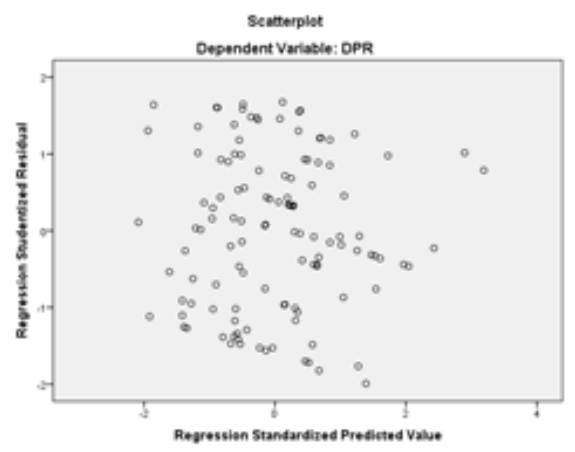

Gambar 3 


\section{Uji Hipotesis (dengan Empat Variabel} Independen)

\section{a. Uji Statistik F}

Berdasarkan hasil uji statistik $t$ yang dilakukan sebelumnya, bahwa variabel $D E R$ tidak memiliki pengaruh yang signifikan terhadap kebijakan dividen oleh karena itu variabel DER harus dikeluarkan dari persamaan regresi kemudian akan dilakukan pengujian ulang. Setelah dilakukan pengujian ulang hanya dengan $C R$, ROA, growth dan firm size sebagai variabel independen maka didapatkan hasil uji statistik F sebagai berikut.

\section{Tabel 8}

\begin{tabular}{|l|r|r|r|r|l|}
\hline \multicolumn{7}{|c|}{ ANOVA $^{\mathbf{a}}$} \\
\hline Model & Sum of Squares & df & Mean Square & F & Sig. \\
\hline 1 Regression & 68.638 & 4 & 12.536 & 6.783 & $.002^{\mathrm{b}}$ \\
\hline Residual & 1079.50 & 115 & 19.467 & & \\
Total & 1148.138 & 119 & & & \\
\hline
\end{tabular}

Berdasarkan tabel 8, nilai $\mathrm{F}$ statistik yang diperoleh menjadi 6.783 dengan nilai signifikansi sebesar 0.002 , lebih kecil dari pada 0.05 , maka dapat disimpulkan bahwa $C R$, ROA, growth dan firm size secara simultan atau bersama-sama memiliki pengaruh yang signifikan terhadap DPR.

\section{b. Uji Statistik t}

Tabel 9

Coefficients $^{\mathrm{a}}$

\begin{tabular}{|c|c|c|c|c|c|}
\hline \multirow[b]{2}{*}{ Model } & \multicolumn{2}{|c|}{ Unstandardized Coefficients } & \multirow{2}{*}{$\begin{array}{c}\text { Standardized Coefficients } \\
\text { Beta } \\
\end{array}$} & \multirow[b]{2}{*}{$t$} & \multirow[b]{2}{*}{ Sig. } \\
\hline & B & Std. Error & & & \\
\hline 1 (Constant) & 24.349 & 6.628 & & 4.897 & .000 \\
\hline $\mathrm{CR}$ & 13.931 & .010 & .113 & 1.763 & .899 \\
\hline ROA & 1.035 & 1.124 & .021 & 0.372 & .022 \\
\hline GROWTH & -25.001 & .016 & -.007 & -.070 & .011 \\
\hline SIZE & .224 & .136 & .062 & 1.650 & .025 \\
\hline
\end{tabular}

Berdasarkan tabel 9 variabel ROA, growth dan firm size dengan nilai signifikan masing-masing berada dibawah 0,05 yang berarti tolak $\mathrm{H}_{0}$ yang berarti bahwa terdapat pengaruh signifikan secara parsial antara variabel terkait terhadap kebijakan dividen.
Sedangkan variabel current ratio (CR) dengan nilai signifikansi sebesar 0,899 yang mana lebih besar dari 0,05 artinya data tidak mampu menolak $\mathrm{H}_{0}$, tidak terdapat pengaruh signifikan secara parsial antara DER dengan kebijakan dividen. Oleh karena itu, variable CR tidak diikutsertakan dalam model regresi dan dilakukan pengujian ulang.

\section{Pengujian Asumsi Klasik (dengan Tiga Variabel Independen) \\ a. Uji Normalitas}

Tabel 10

One-Sample Kolmogorov-Smirnov Test

\begin{tabular}{|c|c|c|}
\hline & & Unstandardized Residua \\
\hline $\mathrm{N}$ & & 120 \\
\hline \multirow[t]{2}{*}{ Normal Parameters 2,6} & Mean & .0000000 \\
\hline & Std. Deviation & 2.14316376 \\
\hline \multirow[t]{3}{*}{ MostExtreme Differences } & Absolute & .257 \\
\hline & Positive & .285 \\
\hline & Negative & -.247 \\
\hline \multicolumn{2}{|l|}{ Kolmogorov-Smimov Z } & .903 \\
\hline \multicolumn{2}{|l|}{ Asymp. Sig. (2-tailed) } & .268 \\
\hline
\end{tabular}

Uji Kolmogorov - Smirnov menunjukkan nilai sebesar 0.268 yang berada di atas 0.05 . Dari hasil pengujian tersebut menunjukkan bahwa data telah terdistribusi normal.

\section{b. Uji Multikolinearitas}

Tabel 11

Coefficients $^{a}$

\begin{tabular}{|c|c|c|c|}
\hline \multirow{2}{*}{ Model } & & \multicolumn{2}{|c|}{ Collinearity Statistics } \\
\hline & & Tolerance & VIF \\
\hline \multirow{4}{*}{1} & (Constant) & & \\
\hline & ROA & 0.85 & 1.045 \\
\hline & GROWTH & 0.94 & 1.044 \\
\hline & SIZE & 0.71 & 1.079 \\
\hline
\end{tabular}

Variabel independen dinyatakan bebas dari multikolinearitas jika mempunyai nilai 
Tolerance di atas 0.1 dan nilai VIF di bawah 10. Dari Tabel 11 dapat diketahui bahwa semua variabel independen memiliki nilai Tolerance di atas 0.1 dan nilai VIF jauh di bawah angka 10. Hal ini menunjukkan dalam model ini tidak terjadi multikolinearitas.

\section{c. Uji Heteroskedastisitas}

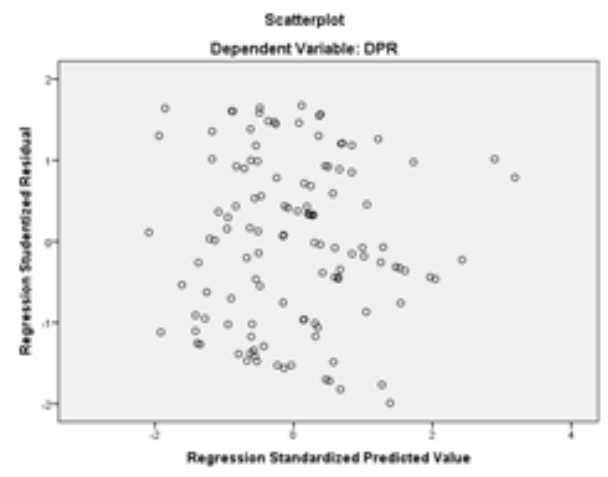

Gambar 4

Pada grafik SRESID dan ZPRED terlihat titik-titik menyebar secara acak dan juga terlihat titik-titik tersebut membentuk suatu pola tertentu. Dengan demikian dapat disimpulkan bahwa penelitian ini terbebas dari masalah heteroskedastisitas.

Setelah melakukan pengujian regresi, maka ditemukan bahwa ada 2 variabel independen yang tidak memberikan pengaruh yaitu variabel $D E R$ dan $C R$. Oleh karena itu, kedua variabel tersebut dikeluarkan dari persamaan regresi. Setelah variabel $D E R$ dan $C R$ dikeluarkan, maka semua variabel independennya menjadi signifikan.

\section{Uji Hipotesis (dengan Tiga Variabel Independen)}

\section{a. Uji Statistik F}

Tabel 12
\begin{tabular}{|l|r|r|r|r|r|}
\hline \multicolumn{1}{|c|}{ ANOVA $^{\mathbf{a}}$} \\
\hline Model & Sum of Squares & df & Mean Square & F & Sig. \\
\hline 1 Regression & 68.748 & 3 & 14.576 & 6.823 & $.001^{\circ}$ \\
\hline Residual & 1077.50 & 116 & 18.497 & & \\
Total & 1148.138 & 119 & & & \\
\hline
\end{tabular}

Berdasarkan tabel 12, nilai $\mathrm{F}$ statistik diperoleh menjadi 6.823 dengan nilai signifikansi sebesar 0.001 , lebih kecil dari pada 0.05 , maka dapat disimpulkan bahwa $R O A$, growth dan firm size signifikan terhadap DPR.

\section{b. Uji Statistik t}

\begin{tabular}{|c|c|c|c|c|c|c|}
\hline & \multicolumn{6}{|c|}{$\begin{array}{l}\text { Tabel } 13 \\
\text { Coefficients }^{\mathrm{a}}\end{array}$} \\
\hline & \multirow{2}{*}{ Model } & \multicolumn{2}{|c|}{ Unstandardized Coefficients } & \multirow{2}{*}{$\begin{array}{c}\text { Standardized Coefficients } \\
\text { Beta } \\
\end{array}$} & \multirow{2}{*}{$\mathrm{t}$} & \multirow{2}{*}{ Sig. } \\
\hline & & $\mathrm{B}$ & Std. Error & & & \\
\hline \multirow{4}{*}{1} & (Constant) & 23.779 & 6.628 & & 3.646 & 0 \\
\hline & ROA & 1.703 & .943 & .166 & 1.806 & 0.022 \\
\hline & GROWTH &. .001 & .016 & -.006 & -.060 & 0.011 \\
\hline & SIZE & -.089 & .136 & -.063 & -.658 & 0.025 \\
\hline
\end{tabular}

Berdasarkan tabel 13 variabel ROA, growth dan firm size dengan nilai signifikan masing-masing berada dibawah 0,05 yang berarti tolak $\mathrm{H}_{0}$ yang berarti bahwa terdapat pegaruh signifikan secara parsial antara variabel terkait terhadap kebijakan dividen.

\section{Analisis Regresi Linear}

Analisis regresi linear digunakan dalam penelitian ini dengan tujuan untuk mengetahui ada tidaknya pengaruh variabel bebas.

Tabel 14

Coefficients $^{\mathrm{a}}$

\begin{tabular}{|c|c|c|c|c|c|c|}
\hline \multicolumn{7}{|c|}{ Coemic } \\
\hline & \multirow{2}{*}{ Model } & \multicolumn{2}{|c|}{ Unstandardized Coefficients } & \multirow{2}{*}{$\begin{array}{c}\text { Standardized Coefficients } \\
\text { Beta }\end{array}$} & \multirow{2}{*}{$\mathrm{t}$} & \multirow{2}{*}{ Sig. } \\
\hline & & $\mathrm{B}$ & Std. Error & & & \\
\hline \multirow{4}{*}{1} & (Constant) & 23.779 & 6.628 & & 3.646 & 0 \\
\hline & ROA & 1.703 & .943 & .166 & 1.806 & 0.022 \\
\hline & GROWTH & -.001 & .016 & -.006 & -.060 & 0.011 \\
\hline & SIZE & -.089 & .136 & -.063 & -.658 & 0.025 \\
\hline
\end{tabular}

$$
\text { DPR }=23.779+1.703 \text { ROA }-0.001
$$

GROWTH - 0.089 SIZE 
a. Nilai konstanta adalah 23.779 artinya apabila variabel $R O A$, growth dan firm size bernilai nol atau tidak ada maka kebijakan dividen akan bernilai sebesar 23.779 .

b. Koefisien regresi variabel ROA sebesar 1.703 artinya jika variabel independen lain nilainya tetap dan ROA mengalami kenaikan $1 \%$, maka kebijakan dividen akan mengalami peningkatan sebesar 1.703. Koefisien bernilai positif artinya terjadi hubungan positif antara ROA dengan kebujakan dividen, semakin naik ROA maka semakin meningkatkan kebijakan dividen.

c. Koefisien regresi variabel growth sebesar -0.001 artinya jika variabel independen lain nilainya tetap dan growth mengalami kenaikan $1 \%$, maka kebijakan dividen akan mengalami penurunan sebesar -0.001. Koefisien bernilai negatif artinya terjadi hubungan negatif antara growth dengan kebijakan dividen, semakin naik growth maka semakin turun kebijakan dividen.

d. Koefisien regresi variabel firm size sebesar -0.089 artinya jika variabel independen lain nilainya tetap dan firm size mengalami kenaikan $1 \%$, maka kebijakan dividen akan mengalami penurunan sebesar -0.089. Koefisien bernilai negatif artinya terjadi hubungan negatif antara growth dengan kebijakan dividen, semakin naik firm size maka semakin turun kebijakan dividen.

\section{Koefisien Determinasi $\left(\mathbf{R}^{2}\right)$}

Berdasarkan hasil penelitian ini menunjukkan bahwa nilai koefisien determinan $\left(\mathrm{R}^{2}\right)$ diperoleh sebesar 0.218 atau $21.8 \%$. Hal ini menunjukkan bahwa $21.8 \%$ dividend payout ratio (DPR) dipengaruhi oleh variabel ROA, growth dan firm size. Sedangkan sisanya sebesar $78.2 \%$ dijelaskan oleh variabel lain.

Tabel 15

Model Summary ${ }^{\mathrm{b}}$

\begin{tabular}{|l|c|c|c|c|}
\hline Model & R & R Square & Adjusted R Square & Std. Error of the Estimate \\
\hline 1 & $489^{\circ}$ & 239 & \\
\hline
\end{tabular}

\section{Simpulan dan Saran}

\section{Simpulan}

1. Hasil analisis menggunakan analisis regresi didapatkan bahwa current ratio (CR) tidak signifikan terhadap dividend payout ratio (DPR) pada perusahaan yang terdaftar di Bursa Efek Indonesia periode 2012-2015. Hal ini ditunjukkan dengan besarnya nilai probabilitas CR sebesar 0,899 yang berada di atas tingkat signifikan 0.05 . Sehingga dapat disimpulkan bahwa hipotesis pertama yang menyatakan bahwa current ratio (CR) berpengaruh signifikan positif terhadap dividend payout ratio (DPR) ditolak. Penelitian ini didukung oleh hasil penelitian Susana (2006), Santosa (2009) dan Sunarto (2005) yang menunjukkan bahwa CR tidak terbukti berpengaruh signifikan terhadap DPR.

2. Hasil analisis menggunakan analisis regresi didapatkan bahwa debt to equity ratio (DER) tidak signifikan terhadap dividend payout ratio (DPR) pada perusahaan yang terdaftar di Bursa Efek Indonesia periode 2012-2015. Hal ini ditunjukkan dengan besarnya nilai probabilitas DER sebesar 0,222 yang berada di atas tingkat signifikan 0.05 . Sehingga dapat disimpulkan bahwa hipotesis kedua yang menyatakan bahwa debt to equity ratio (DER) berpengaruh negatif terhadap dividend payout ratio (DPR) ditolak. Penelitian ini didukung oleh hasil penelitian Prasetyo (2013), Deitiana (2009) dan Sutari (2011) yang menunjukkan bahwa DER tidak terbukti berpengaruh signifikan terhadap DPR.

3. Hasil analisis menggunakan analisis regresi didapatkan bahwa return on asset (ROA) berpengaruh positif dan signifikan terhadap dividend payout ratio (DPR) pada perusahaan yang terdaftar di Bursa Efek Indonesia periode 2012-2015. Hal ini ditunjukkan dengan besarnya nilai probabilitas return on asset sebesar 0,022 yang 
berada di bawah tingkat signifikan 0.05 . Hasil ini menjelaskan bahwa semakin tinggi return on asset maka mengakibatkan meningkatnya dividend payout ratio. Sehingga dapat disimpulkan bahwa hipotesis ketiga yang menyatakan bahwa return on asset (ROA) berpengaruh signifikan positif terhadap dividend payout ratio (DPR) dapat diterima. Penelitian ini didukung oleh hasil penelitian Parthington (1989), Prasetyo (2013) dan Syahbana (2006) yang menujukkan bahwa ROA terbukti berpengaruh signifikan terhadap DPR.

4. Hasil analisis menggunakan analisis regresi didapatkan bahwa growth berpengaruh negatif dan signifikan terhadap dividend payout ratio (DPR) pada perusahaan yang terdaftar di Bursa Efek Indonesia periode 2012-2015. Hal ini ditunjukkan dengan besarnya nilai probabilitas growth sebesar 0,011 yang berada di bawah tingkat signifikan 0.05 . Sehingga dapat disimpulkan bahwa hipotesis keempat yang menyatakan bahwa growth berpengaruh signifikan negatif terhadap dividend payout ratio (DPR) dapat diterima. Hasil penelitian ini konsisten dan mendukung hasil penelitian dari Abdullah (2001) dan Nadjibah (2008) dimana hasil penelitiannya menunjukkan bahwa growth memiliki pengaruh yang signifikan terhadap dividend payout ratio (DPR) dan hasil penelitian yang dilakukan oleh Amidu dan Abor (2006) menyatakan bahwa terdapat hubungan negatif antara dividend payout ratio dengan growth.

5. Hasil analisis menggunakan analisis regresi didapatkan bahwa firm size berpengaruh negatif dan signifikan terhadap dividend payout ratio (DPR) pada perusahaan yang terdaftar di Bursa Efek Indonesia periode 2012-2015. Hal ini ditunjukkan dengan besarnya nilai probabilitas size sebesar 0,025 yang berada di bawah tingkat signifikansi 0.05. Sehingga dapat disimpulkan bahwa hipotesis kelima yang menyatakan bahwa firm size berpengaruh signifikan negatif terhadap dividend payout ratio (DPR) dapat diterima. Penelitian ini didukung oleh hasil penelitian Aruna (2003), Amalia (2008), Sutan (2011) dan Atika (2002) dimana hasil penelitiannya menunjukan bahwa firm size memiliki pengaruh yang signifikan terhadap $D P R$.

6. Hasil penelitian diperoleh nilai adjusted $\mathrm{R}^{2}$ sebesar 0.218 yang berarti bahwa $21.8 \%$ variasi dividend payout ratio dapat dijelaskan oleh ketiga variabel independen yaitu ROA, growth dan firm size. Sedangkan sisanya sebesar $78.2 \%$ dijelaskan oleh variabel lain di luar model.

\section{Saran}

Berdasarkan hasil penelitian, peneliti mengungkapkan saran sebagai berikut:

\section{Bagi Investor}

Investor harus menganalisis kinerja dan prospek saham terlebih dahulu sebelum melakukan investasi saham, yaitu dengan mempertimbangkan besarnya Likuiditas (CR), Solvabilitas (DER), Profitabilitas (ROA), growth dan firm size yang akan mempengaruhi pengambilan kebijakan dividen perusahaan emiten.

\section{Bagi Manajemen}

Hasil penelitian ini menunjukkan bahwa hanya tiga variabel, yaitu return on assets, growth dan firm size yang berpengaruh terhadap dividend payout ratio secara signifikan, sedangkan current ratio dan debt to equity ratio tidak berpengaruh secara signifikan terhadap dividend payout ratio. Dengan demikian bagi pihak manajemen yang ingin memaksimalkan pembayaran dividend payout ratio kepada pemegang saham diharapkan dapat fokus pada tiga variabel yaitu return on assets, growth dan firm size. 


\section{Bagi Peneliti Selanjutnya}

1. Penelitian ini menggunakan lima variabel sebagai prediktor, sedangkan dalam kenyataannya masih banyak variabel yang lain yang dapat mempengaruhi jumlah DPR. Oleh karena itu, untuk peneliti selanjutnya disarankan agar mengikutsertakan variabel lain yang masih relevan dengan penelitian, seperti cash ratio, free cash flow, kepemilikan perusahaan ROI, DTA dan yang lainnya.

2. Penelitian ini hanya terbatas pada pengamatan terhadap 30 sampel serta periode pengamatan hanya 6 tahun saja. Maka untuk penelitian selanjutnya diharapkan dapat menggunakan rentang periode yang lebih panjang dan sampel yang lebih banyak.

\section{Daftar Pustaka}

Abdullah, Faisal M. 2001. Dasar-dasar Manajemen Keuangan. Universitas Muhammadiyah Malang, Jawa Timur.

Amalia. 2008. Analisis Pengaruh Investasi, Likuiditas, Profitabilitas, Pertumbuhan Perusahaan, dan Ukuran Perusahaan terhadap Kebijakan Dividen Payout Ratio. Vol. 5, Nomor 1, p. 51-62

Amidu, Mohammed and Joshua Abor. 2006. Determinants of Dividend Payout Ratios in Ghana. The Journal of Risk Finance. Vol. 7, Nomor. 2, pp. 136 -145.

Aruna. 2003. Fundamental of Financial Management. Jakarta: Salemba Empat.

Atika. 2002. Faktor-Faktor yang Mempengaruhi Kebijakan Dividen: Investigasi Pengaruh Teori Stakeholder. JAAI Vol. 6 Nomor 2, Desember 2002.
Cendekia dan Irine. 2010. Manajemen Keuangan. Yogyakarta: Media Persindo.

Deitiana, Tita. 2009. Faktor-Faktor yang Mempengaruhi Kebijakan Pembayaran Dividen Kas. Jurnal Bisnis dan Akuntansi, Vol. 11, Nomor 1, Hal 57-64.

Kasmir. 2012. Analisis Laporan Keuangan. PT. Raja Grafindo Persada: Jakarta.

Kasmir dan Jakfar. 2012. Studi Kelayakan Bisnis Edisi Revisi. Penerbit Kencana: Jakarta.

Nadjibah, 2008. Analisis Pengaruh Asset Growth, Size, Cash Ratio, Return On Asset terhadap Dividen Kas Pada Perusahaan Manufaktur Yang Go Public di BEI. Skripsi. Semarang: Fakultas Ekonomi Universitas Diponegoro Semarang.

Orniati, Yuli. 2009. Laporan Keuangan sebagai Alat untuk Menilai Kinerja Keuangan. Jurnal Ekonomi Bisnis, Vol. 14, Nomor 3.

Santosa. 2009. Faktor-faktor yang Mempengaruhi Dividen Kas Perusahaan Manufaktur Di Bursa Efek Indonesia. Jurnal.Surabaya: Fakultas Ekonomi UPN Veteran.

Sugiyono. 2010. Metode Penelitian Bisnis. Bandung: Alfabeta.

Sunarto. 2005. Analisis Faktor-faktor Yang Mempengaruhi Dividen Per Share Perusahaan-perusahaan Yang Go Public di Bursa Efek Indonesia.

Susana. 2006. Uji Normalitas. Semarang: Universitas Negeri Semarang.

Sutari. 2011. Akuntansi Keuangan Menengah. Jilid I. Jakarta: Salemba Empat.

Sutoyo. T., Edy Mulyanto, Vincent Suhartono, Oky Dwi Nurhayati dan Wijanarto. 2011. Analisis Pengaruh Return On Assets, Return On Equity dan Debt to Equity Rasio terhadap Dividend Payout Ratio. Yogyakarta:Penerbit ANDI. 
Syahbana. 2006. Analisis Regresi dan Uji

Hipotesis. Medpress, Yogyakarta.

Swastyastu M. W, Yuniarta G. A dan Atmadja. 2014. Analisis FaktorFaktor yang Mempengaruhi Kebijakan Dividend Payout Ratio yang terdaftar di Bursa Efek Indonesia (BEI). E-Jurnal SI Akuntansi Universitas Pendidikan Ganesha Jurusan Akuntansi Program S1. Vol. 2, Nomor 1.

Parthington. 1989. Dividend Policy: Case study Australian Capital market. Journal of Finance: pp. 155-176.

Prasetyo, Dimas. 2013. Pengaruh Keputusan Investasi dan Keputusan Pendanaan Terhadap Nilai Perusahaan. Jurnal Manajemen Bisnis.

Rizqia, Dwita Ayu. 2013. Effect of Managerial Ownership, Financial Leverage, Profitability, Firm Size and Investment Opportunity on Dividend Policy and Firm Value. Research Journal of Finance and Accounting. Vol. 4, Nomor 11.

\section{Internet:}

www.idx.co.id. 